\title{
Comparative study of amaranth species (Amaranthus spp.) in the temperate continental climate of Russian Federation
}

\author{
Oksana DMITRIEVA $^{1,2, \text { Semen IVANOV }}{ }^{3}$
}

Received September 26, 2019; accepted December 2, 2019. Delo je prispelo 26. septembra 2019, sprejeto 2. decembra 2019.

Primerjalna raziskava vrst ščira (Amaranthus spp.) v zmernem kontinentalnem podnebju Ruske Federacije

Izvleček: Poljski poskus je bil izveden v Čuvaški republiki, v osrednem delu evropskega dela Rusije, na bregovih Volge, ki ima zmerno kontinentalno podnebje s toplimi poletji, mrzlimi zimami, $\mathrm{z}$ dobro izraženimi prehodnimi obdobji in s povprečno letno količino padavin $500 \mathrm{~mm}$. Na območju uspeva več gojenih in podivjanih vrst ščira $\mathrm{z}$ različnimi morfološkimi in biološkimi lastnostmi. Predmet raziskave so bile štiri pogoste vrste ščira: A. cruentus L., A. caudatus L., A. hybridus L., A. spinosus L.. Posebna pozornost je bila posvečena morfološkim in biološkim lastnostim rastlin glede na fazo v rastni sezoni, tvorbi biomase in zrnja v 3 letih raziskav. Kot rezultat poskusa je bila dokazana možnost gojitve toploljubnih ščirov v klimatski razmerah Čuvaške republike, za zeleno biomaso vrsti A.cruentus and A.caudatus in za zrnje vrsto A.cruentus.

Ključne besede: A. cruentus; A. caudatus; A. hybridus; A. spinosus; rastna sezona; faze rasti; prilagodljiva vrsta

1 I. N. Ulyanov Chuvash state University, Medical faculty, Department of medical biology with Microbiology and Virology course, Cheboksary, Chuvash Republic, Russian Federation

2 Corresponding author, e-mail: dofa1967@mail.ru

3 Ministry of natural resources and ecology of the Chuvash Republic, Cheboksary, Chuvash Republic, Russian Federation 


\section{INTRODUCTION}

Agriculture faces a great pressure to produce greater quantities of food, feed and biofuel on declining land resources for the projected nine billion people on the planet by 2050 (Godfray et al., 2010). It is predicted that agricultural production has to increase by $70 \%$ by 2050 to cope with an estimated $40 \%$ increase in world population. So, utilization of underutilized food crop performs a massive function for providing food, feed and vitamins to such increasing population (Bruinsma, 2009). In recent years producers and consumers have been interested in new plant species, which are referred as alternative plants or new crops. Whether they are actually new or just recently rediscovered, these species not only create valuable crude material for a number of industrial branches but they also constitute an important source of renewable energy. In addition, they add to the human menu, making it more diverse (Rastogi \& Shukla, 2013). Amaranth is one of the few multipurpose crops who provide grain, leafy vegetable, fodder, and greater diet then the predominant staple crops. Nutrition value and use of grain amaranth is a potential future application in bread making (Mlakar et al., 2009).

It is a tremendously short-lived annual, which develop vigorously, drought resistant and adapt effortlessly to new environments. It originates from tropical America, archeological excavations proved it also in India but from tropical America is has spread all over the tropical World, as China, Nepal, Italy, Greece, Africa, and Australia (Ozsoy, 2009). Amaranth is not a "true cereal" such as wheat, corn or barley, but it is considered as "pseudo-cereal" like buckwheat (Fagopirum esculentum Moench) and quinoa (Chenopodium quinoa Willd.). Amaranth belongs to the order of Caryophyllales and family of Amaranthaceae and to the genus of Amaranthus. Amaranth leaves have excellentl chemical composition with mild spinach-like taste so it comes beneath an accurate leafy vegetable (Amicarelli \& Camaggio, 2012).

Amaranth species (A. blitum L., A. caudatus L., A. cruentus L., A. tricolor L.) are collectively known as amaranths or pigweed. They have a common name such as African spinach, India spinach and Chinese spinach; approximately 60 species are recognized with inflorescence and foliage ranging from purple and red to gold. Members of this genus share many characteristics and uses with members of the closely related genus Celosia (Juan, 2007).

Amaranth originates from South America, from where it was widely distributed in most tropical regions and has been used as a grain, leafy vegetable and forage crop (Ebert, 2010). Amaranths could be divided into two groups, based on their consumption, grain and vegetable amaranths. Species grown for vegetables are represented mainly by A. tricolor, A. dubius, A. lividus L., A. creuntus,
A. palmeri S. Wats. and A. hybridus. Three principal species considered for grain include, $A$. hypochondriacus L., A. cruentus and A. caudatus (Topwal, 2019).

Amaranth is a dicotyledonous, herbaceous plant with an erect stem and large inflorescence. Amaranth is $\mathrm{C}_{4}$ plant and belongs into group of NAD-malic enzyme-type of $\mathrm{C}_{4}$ metabolism. Some anatomical characteristics of amaranth and its $\mathrm{C}_{4}$-photosynthesis pathway result in increased efficiency of the usage of $\mathrm{CO}_{2}$ below an extensive vary of temperature (from $25^{\circ} \mathrm{C}$ to $40^{\circ} \mathrm{C}$ ), below greater mild intensity, and moisture stress environments. All this contribute to the crop's huge geographic adaptability to numerous environmental conditions (Kaufman, 1992). Amaranth leaves can be used as greens in salads, boiled or fried in oil and mixed with meat or fish. This can be used as side dish in soups or as an ingredient in sauce and baby food (Mlakar et al., 2010). The leaves are high in fibers and contain high concentration of vitamin A, B6 and C, riboflavin and foliate. Minerals include calcium, iron, magnesium, phosphorus, potassium, zinc, copper and manganese. An amaranth grain can be ground for use in bread, noodle, pancakes, cereals, granola cookies or other flour baked products. More than 40 products containing amaranths are currently on the market in the USA (Putnam, 2007). Leafy vegetables of amaranth supply protein, minerals and vitamins in diet. Their lush, green, succulent crisp are eaten raw or cooked as vegetables in soup, they are best when the plant is young and tender. Amaranth grain is high in protein and contains two essential amino acids: lysine and methionine, which are frequently found in other cereal grains. It is higher in fiber and iron than wheat, and higher in calcium (Uusikua, 2010). Amaranth is a widely adapted genus, and can be grown in different climate conditions. But the more limiting factor is the temperature and less limiting is the rainfall amount during the growing season (Dmitrieva, $2018 \mathrm{~b}$ ). Amaranth can be grown together with corn and sunflower to obtain high-nutrient silage. To do this, the seeds of amaranth, corn and sunflower are sown in separate rows in one field and cut together for silage without mixing in the future (Dmitrieva, 1993).

The aim of the research was to compare amaranth species (Amaranthus spp.) by morphological and biological characteristics and to determine adaptive species among them for cultivation for fodder and grain purposes in the soil and climatic conditions of the Chuvash Republic.

\section{MATERIALS AND METHODS}

\subsection{FIELD EXPERIMENT}

Field experiment was conducted in period from 
2015 to 2017 at the experimental field of the University located on the right Bank of the Volga river in Cheboksary $\left(53^{\circ} 58^{\prime} \mathrm{N} ; 47^{\circ} 15^{\prime} \mathrm{E}\right)$. The soil type of the experimental field is light gray forest loam, medium podzolic according to the Russian classification that corresponds to soils with average nutritional values (Shishova et al., 2004). The $\mathrm{pH}$ of the salt extract $\left(\mathrm{pH}_{\mathrm{kcl}}\right)$ is 5.4 , the humus content according to Tyurin is $2.2 \%$. The arable layer was characterized by moderate concentrations of phosphorus (12.0 mg $100 \mathrm{~g}^{-1}$ of soil), potassium (12.0 mg $100 \mathrm{~g}^{-1}$ of soil) and magnesium (4.5 mg $100 \mathrm{~g}^{-1}$ of soil). The thickness of the arable horizon is $21-23 \mathrm{~cm}$, relief the fields is flat. Judging by the agrochemical characteristics, the soils of the experimental plot do not have the properties to obtain high yields of amaranth without the application of mineral fertilizers. There was one background of mineral nutrition in the experiment. Before sowing, $\mathrm{N}$, $\mathrm{P}, \mathrm{K}$ fertilizers were applied to all plots at the following rates: $60 \mathrm{~kg} \mathrm{~N} \mathrm{ha}^{-1}, 80 \mathrm{~kg} \mathrm{P}_{2} \mathrm{O}_{5} \mathrm{ha}^{-1}$ and $90 \mathrm{~kg} \mathrm{~K}_{2} \mathrm{O} \mathrm{ha}^{-1}$ according to soil analysis. The area of the experimental plot was $40 \mathrm{~m}^{2}$ respectively $10 \mathrm{~m}^{2}$ for each species of amaranth. The experiment had a randomized block design with four replications.

The analyzed species were four of the most common species of amaranth (Amaranthus spp.): A. cruentus, $A$. caudatus, A. hybridus, A. spinosus. from different groups of plants according to plant height: long-stemmed, medium-stemmed and short-stemmed (Table 1).

Every year, amaranth was sown after potatoes. Since the seeds are very small (mass of 1000 seeds is $0.6 \mathrm{~g}$ ) amaranth requires thorough soil preparation in the spring (double loosening of the soil to a depth of 6 and $8 \mathrm{~cm}$ ). For the same reason seeds were mixed with sand at a ratio of $1 \mathrm{~g}$ seed to $100 \mathrm{~g}$ sand to facilitate the sowing process and to obtain a uniform stand (Dmitrieva, 2018a, Fadeeva \& Dmitrieva, 2017). Seeds were sown in late May at soil temperatures above $16-18{ }^{\circ} \mathrm{C}$ to a depth of $1 \mathrm{~cm}$. Method of planting was broadcasting and seeds were spaced at $70 \mathrm{~cm}$ between rows. Seeding rate was $1.0 \mathrm{~kg} \mathrm{ha}^{-1}$. Weeding was done using hoe. First weeding was carried out at two weeks after sowing and second weeding at 4 weeks after sowing. Harvesting for green mass (silage) and grain was done by cutting the whole plant on different dates depending on the Amaranthus spp. and weather conditions (Table 2). Observations of plant growth, plant height, number of leaves per plant, leaf area were carried out in accordance with the growth stages: vegetative state, inflorescence formation, flowering, seed maturation. To measure plant height a meter ruler was used to take the height of four tagged plants of amaranths in each experimental unit, and the mean was calculated and recorded. The height was measured from the ground level to the tip of the plant. Leaves of four tagged plants were counted in each experimental, and the mean was determined and recorded. Only fully opened leaves were counted. To calculate the leaf area, the length and width were multiplied using the constant (6.6) for four tagged plants of each amaranth species. The fresh mass of the plants was determined after cutting of whole plant in the net plots, and then extrapolated to per hectare. The harvested amaranth (dry mass of the plant) was dried on $60-70{ }^{\circ} \mathrm{C}$ in laboratory and weighed to determine the dry mass of the net plot and then extrapolated to per hectare. Seeds were harvested once when inflorescence change color to yellow or pink. Plants were cut, threshed and seed cleaned. Seed harvesting was carried out by cutting inflorescences and threshing seeds only in dry and warm weather for two weeks (Table 2). The content of nutrients in the green mass and grain (protein, lipids, carotene, sugar) was determined in the agrochemical laboratory of the Universityby near infrared spectroscopy (Russian Organization for Standardization, 2012).

\subsection{WEATHER CONDITIONS}

Chuvash Republic has moderately continental climate with warm summers, cold winters, well-defined transitional seasons and average annual rainfall of $500 \mathrm{~mm}$. Weather conditions during 2015-2017 are presented in Table 2 . The information is given together with the dates of sowing and harvesting and respectively the duration of the growing season of $A$. cruentus and with such indicators as the rainfall amount and the amount of active temperatures above $10{ }^{\circ} \mathrm{C}$ accumulated during the growing season $\left(\sum T>10^{\circ} \mathrm{C}\right)$.

Table 2 shows that growing season for the formation

Table1: Description of amaranth species (Amaranthus spp.) used in the experiment

\begin{tabular}{|c|c|c|c|c|c|c|}
\hline Amaranthus spp. & Height group & Origin & Stem colour & Inflorescence form & Inflorescence colour & Seed colour \\
\hline A. cruentus & long-stemmed & USA & Pink & Erect & Pink & Black \\
\hline A. caudatus & long-stemmed & USA & Pink & Drooping & Pink & Pink \\
\hline A. hybridus & medium-stemmed & China & Green & Erect & Green & Cream \\
\hline A. spinosus & short-stemmed & India & Green & Erect & Green & Cream \\
\hline
\end{tabular}


Table 2: Weather conditions for the growing season of A. cruentus in the years 2015-2017

\begin{tabular}{|c|c|c|c|c|c|}
\hline Years & Seeding date & Harvest date & Growing season & Rainfalls (mm) & $\Sigma T>10^{\circ} \mathrm{C}$ \\
\hline \multicolumn{6}{|c|}{ Green fresh mass (biomass) } \\
\hline 2015 & 23 May & 20 August & 91 & 165 & 1496 \\
\hline 2016 & 25 May & 17 August & 85 & 178 & 1654 \\
\hline 2017 & 23 May & 18 August & 87 & 269 & 1636 \\
\hline Average & & & 88 & 204 & 1595 \\
\hline \multicolumn{6}{|c|}{ Grain (seeds) } \\
\hline 2015 & 23 May & 19 September & 120 & 215 & 1850 \\
\hline 2016 & 25 May & 10 September & 109 & 222 & 2080 \\
\hline 2017 & 23 May & 9 September & 111 & 298 & 2112 \\
\hline Average & & & 113 & 245 & 2014 \\
\hline
\end{tabular}

of green mass for silage in 2016 and 2017 was shorter due to warmer weather $\left(\sum T>10{ }^{\circ} \mathrm{C}-1654{ }^{\circ} \mathrm{C}\right.$ and $\left.1636{ }^{\circ} \mathrm{C}\right)$ and was not particularly dependent on rainfall. The same situation was observed in the cultivation of grain amaranth when $\Sigma T>10^{\circ} \mathrm{C}$ accumulated up to $2080-2112^{\circ} \mathrm{C}$. In general, it can be noted that the weather conditions of Chuvash Republic were quite optimal for formation of green fresh mass (biomass) and seeds of A. cruentus during the years of the experiment.

\subsection{STATISTICAL ANALYSIS}

The results were processed statistically by analysis of variance (One-Way ANOVA) in the Statistica 12.0 program. The significance of differences was determined with Tukey's test at $p<0.05$.

\section{RESULTS AND DISCUSSIONS}

\subsection{GROWTH ANALYSIS OF AMARANTH SPE- CIES (Amaranthus SPP.)}

Amaranth growing season includes the following growth stages from sowing to mature seeds: seedlings, vegetative state, inflorescence formation, flowering, seed maturation. Each growth stage was determined at the time when it was observed in $75 \%$ of the control plants (Dmitrieva, 2018c). The results of growth stages duration of amaranth species in the years of the experiment are presented in Table 3.

Table 3 shows that all amaranth species (Amaranthus spp.) have two longest stages of growth: vegetative state reaching 35-45 days and flowering reaching 28-45 days. Comparing species in the vegetative state when plants form the root system and stems with leaves it is determined that $A$. cruentus passes this period faster by 8-16 days which is a good indicator for temperate climatic conditions of the experiment. These results are compatible with those reported by investigators (Thapa \& Blair, 2018; Saratovsky et al., 2018). The same pattern was observed during flowering when the same species $A$. cruentus bloomed 6-17 days earlier compared to other species that made it possible to grow $A$. cruentus for grain in these conditions for three years of experiment. As a result, during the growing season $A$. cruentus formed biomass for silage for 88 days and after 24-29 days of seed maturation formed grain suitable for use for fodder and food purposes. A. caudatus having a growing season of about 100 days is also suitable for growing fresh biomass for silage in experimental conditions. But analysis of the growth stages showed their longer duration due to lack of heat that contributed only to the partial maturation of seeds. A. hybridus was distinguished by the longest duration of the growing season and did not have time to grow to full flowering due to higher requirements for temperature (Costea et al., 2001). In general, the climatic conditions of the Chuvash Republic allow growing all amaranth species for fresh green biomass but considering the early onset of frost it is preferable to grow species with a shorter growing season (A. cruentus, A. caudatus).

The main indicator of the physiological state is the growth of plants. Therefore, the experiment involved the analysis of changes in the linear growth (height) and stem diameter of amaranth species. Amaranth species differed significantly in height and were conventionally divided into three groups: long-stemmed (A. cruentus, A. caudatus), medium-stemmed ( $A$. hybridus), shortstemmed (A. spinosus). The change in plant height during the growing season is presented in Table 4.

Table 4 shows that early stages of all amaranth species growth were characterized by very slow growth of the stem and leaves due to the small supply of nutrients 
Table 3: Duration of amaranth species (Amaranthus spp.) growth stages (days)

\begin{tabular}{|c|c|c|c|c|}
\hline Growth stages & A. cruentus & A. caudatus & A. hybridus & A. spinosus \\
\hline \multicolumn{5}{|l|}{2015} \\
\hline Seedlings & 15 & 15 & 15 & 15 \\
\hline Vegetative state & 34 & 42 & 45 & 40 \\
\hline Inflorescence formation & 14 & 14 & 15 & 15 \\
\hline Flowering & 30 & 35 & 45 & 30 \\
\hline Growing season (biomass) & 91 & 106 & 120 & 100 \\
\hline Seed maturation & 29 & - & - & - \\
\hline Growing season (grain) & 120 & - & - & - \\
\hline \multicolumn{5}{|l|}{2016} \\
\hline Seedlings & 12 & 12 & 12 & 12 \\
\hline Vegetative state & 35 & 42 & 45 & 40 \\
\hline Inflorescence formation & 12 & 12 & 14 & 14 \\
\hline Flowering & 26 & 32 & 45 & 30 \\
\hline Growing season (biomass) & 85 & 98 & 116 & 96 \\
\hline Seed maturation & 24 & - & - & - \\
\hline Growing season (grain) & 109 & - & - & - \\
\hline \multicolumn{5}{|l|}{2017} \\
\hline Seedlings & 12 & 12 & 12 & 12 \\
\hline Vegetative state & 36 & 44 & 45 & 40 \\
\hline Inflorescence formation & 10 & 10 & 12 & 11 \\
\hline Flowering & 29 & 33 & 45 & 31 \\
\hline Growing season (biomass) & 87 & 99 & 114 & 94 \\
\hline Seed maturation & 24 & - & - & - \\
\hline Growing season (grain) & 111 & - & - & - \\
\hline \multicolumn{5}{|l|}{ 2015-2017 } \\
\hline Seedlings & 13 & 13 & 13 & 13 \\
\hline Vegetative state & 35 & 43 & 45 & 40 \\
\hline Inflorescence formation & 12 & 12 & 14 & 13 \\
\hline Flowering & 28 & 33 & 45 & 31 \\
\hline Growing season (biomass) & 88 & 101 & 117 & 97 \\
\hline Seed maturation & 25 & - & - & - \\
\hline Growing season (grain) & 113 & - & - & - \\
\hline
\end{tabular}

in small seeds. During this period, the root system developed very actively from seedlings to inflorescences. After 4-5 weeks, intensive plant growth began in the middle of the vegetative stage and reached $40 \mathrm{~cm}$ in long-stemmed, $30 \mathrm{~cm}$ in medium-stemmed and $16 \mathrm{~cm}$ in short-stemmed of amaranth species (Amaranthus spp.). Since the inflorescence formation, the growth of the stem and the increase in its diameter were very active and by the end of flowering when harvesting green biomass for silage reached maximum height of $173-175 \mathrm{~cm}$ and a diameter of more than $2.0 \mathrm{~cm}$ (A. cruentus, A. caudatus), $150 \mathrm{~cm}$ and $1.7 \mathrm{~cm}$ (A. hybridus), $71 \mathrm{~cm}$ and $0.7 \mathrm{~cm}$ (A. spinosuss). Plant growth during this period was due to the growth of a long inflorescence and in the previous stages due to the elongation of the internodes of the stem. The same results were reported by other investigators. They noted the maximum growth of plants in the period between formation of inflorescences and flowering (Abbas et al., 2017; Carlquist, 2003; Archipova \& Breus, 2004). It was determined that the daily increase in plant height 
Table 4: Dynamics of changes in plant height and stem diameter of amaranth species (Amaranthus spp.) during the growing season in the year $2016(\mathrm{~cm})$

\begin{tabular}{|c|c|c|c|c|}
\hline Growth stages & A. cruentus & A. caudatus & A. hybridus & A. spinosus \\
\hline \multicolumn{5}{|l|}{ Plant height } \\
\hline Seedlings & $5.5 \mathrm{a}$ & $5.5 \mathrm{a}$ & $5.2 \mathrm{a}$ & $5.4 \mathrm{a}$ \\
\hline Vegetative state & $37.9 \mathrm{a}$ & $39.0 \mathrm{a}$ & $28.8 \mathrm{~b}$ & $16.4 \mathrm{c}$ \\
\hline Inflorescence formation & $91.0 \mathrm{a}$ & $93.6 \mathrm{a}$ & $66.6 \mathrm{~b}$ & $40.8 \mathrm{c}$ \\
\hline Flowering & $173.3 \mathrm{a}$ & $175.2 \mathrm{a}$ & $150.0 \mathrm{~b}$ & $71.4 \mathrm{c}$ \\
\hline Seed maturation & 186.9 & - & - & - \\
\hline \multicolumn{5}{|l|}{ Stem diameter } \\
\hline Seedlings & $0.3 \mathrm{a}$ & $0.3 \mathrm{a}$ & $0.3 \mathrm{a}$ & $0.2 \mathrm{a}$ \\
\hline Vegetative state & $0.7 \mathrm{a}$ & $0.7 \mathrm{a}$ & $0.6 \mathrm{a}$ & $0.4 \mathrm{~b}$ \\
\hline Inflorescence formation & $1.6 \mathrm{a}$ & $1.5 \mathrm{a}$ & $1.2 \mathrm{~b}$ & $0.7 \mathrm{c}$ \\
\hline Flowering & $2.2 \mathrm{a}$ & $2.1 \mathrm{a}$ & $1.7 \mathrm{~b}$ & $1.0 \mathrm{c}$ \\
\hline Seed maturation & 2.2 & - & - & - \\
\hline
\end{tabular}

Values within a lines marked with different letter are significantly different at $p<0.05$.

Table 5: Dynamics of changes in number of leaves and leaf area of amaranth species (Amaranthus spp.) during the growing season in the year 2016

\begin{tabular}{lllll}
\hline Growth stages & A. cruentus & A. caudatus & A. hybridus & A. spinosus \\
\hline Number of leaves & & & & \\
\hline Vegetative state & $10.5 \mathrm{a}$ & $10.0 \mathrm{a}$ & $9.5 \mathrm{a}$ & $7.0 \mathrm{~b}$ \\
Inflorescence formation & $30.9 \mathrm{a}$ & $28.7 \mathrm{a}$ & $27.2 \mathrm{a}$ & $21.4 \mathrm{~b}$ \\
Flowering & $59.2 \mathrm{a}$ & $57.4 \mathrm{a}$ & $54.7 \mathrm{a}$ & $39.3 \mathrm{~b}$ \\
Seed maturation & 64.9 & - & & - \\
\hline Leaf area $\left(\mathrm{cm}^{2}\right)$ & & & $429.4 \mathrm{a}$ & $289.6 . \mathrm{b}$ \\
Vegetative state & $446.9 \mathrm{a}$ & $450.2 \mathrm{a}$ & $1907.6 \mathrm{a}$ & $1686.1 \mathrm{~b}$ \\
Inflorescence formation & $2007.5 \mathrm{a}$ & $1988.8 \mathrm{a}$ & $4689.8 \mathrm{a}$ & $3044.5 \mathrm{~b}$ \\
Flowering & $4796.7 \mathrm{a}$ & $4773.3 \mathrm{a}$ & - & - \\
Seed maturation & 5710.4 & - & &
\end{tabular}

Values within a lines marked with different letter are significantly different at $p<0.05$.

was $5 \mathrm{~cm}$ in the flowering stage and $2 \mathrm{~cm}$ throughout the growing season. A. cruentus and A. caudatus had the best and significantly different indicators of growth processes and are preferred for growing in climatic conditions of the experiment.

Plant growth depends on metabolic processes and, above all, on the photosynthetic activity of the plant organism. Therefore, it is necessary to select such forms of plants that have a high capacity of photosynthesis and a high rate of growth processes. Number of plant leaves plays an important role because they manufacture and supply food material synthesized during photosynthesis. Favorable conditions for harvest formation of the plants are created when the leaf area exceeds 3 times the area of the plant and the leaves do not shade each other (Taipova \& Kuluev, 2015; Dmitrieva, 2014). The change in number of leaves and leaf area of one plant during the growing season is presented in Table 5 .

Analysis of the increase in the number of leaves showed the same pattern as with the height of plants according to the growth periods. The maximum increase in the number of leaves and the leaf area per plant was established after vegetative state and inflorescence formation until the end of flowering at the time of harvesting green biomass for silage (Betschart et al., 2001; Saratovsky et al., 2018). The number of leaves and leaf area in these stages increased by 2-4 times and reached 55-60 leaves and 4600-4800 $\mathrm{cm}^{2}$ in long-stemmed and 
medium- stemmed species, 40 leaves and $3000 \mathrm{~cm}^{2}$ in short-stemmed of amaranth species (Amaranthus spp.). The area of one plant in the experiment was $700 \mathrm{~cm}^{2}$, the leaf area of $A$. cruentus and A. caudatus was 7 times larger and reached more than $5000 \mathrm{~cm}^{2}$, which indicates the optimal ratio of these parameters for photosynthesis and as a result for better growth and development of plants in the climatic conditions of the experiment. Magomedov (2008) made similar experiments in the Republic of Tatarstan and observed the same pattern in the development of the leaf surface during the amaranth growth.

\subsection{YIELD OF AMARANTH SPECIES (Amaranthus spp.)}

Yield is a comprehensive generalizing indicator of the degree of favorable growth conditions for the cultivation of agricultural plants. To determine the yield it is necessary to analyze the increase in fresh and dry mass of plants during growth periods, which are presented in Table 6.

Table 6 shows that since the growth processes were not so active in the first 50 days after sowing, the increase in fresh and dry biomass of all amaranth species (Amaranthus spp.) was not intensive during this period. From the stage of inflorescence formation to the end of flowering within 40-50 days, fresh and dry biomass increased almost 5 times (from 12.4 to $57.2 \mathrm{t} \mathrm{ha}^{-1}$ fresh mass and from 2.0 to $10.6 \mathrm{t} \mathrm{ha}^{-1}$ dry mass in A. cruentus) due to active growth in length, thickening of the stem, increasing the number of leaves and elongation of inflorescences
(Pospisil et al., 2009; Ulbricht et al. 2009). The same pattern was observed with other species of amaranth. Comparing amaranth species found a significant increase in biomass in the group of long-stemmed species (A. cruentus and A. caudatus) due to more active growth in length, thickening of the stem, increasing the number of leaves and elongation of inflorescences. The dry matter content increased from $16 \%$ in the vegetative state to $18.5 \%$ at the end of flowering when harvesting fresh green biomass (Norman \& Shongwe, 1993).

Comparing Amaranthus spp. found that the dry matter content did not differ significantly depending on the species of amaranth. By the time of harvesting mature A. cruentus seeds, the dry matter content increased by another $1 \%$. The results of the yield of fresh green biomass at the end of the flowering stage and mature seeds are presented in Table 7 .

Yield analysis of fresh green biomass showed that all amaranth species except $A$. spinosus had high biological productivity. Soil and climatic conditions during the experiment allowed the plants to form well-developed stems, leaves, inflorescences that contributed to intensive photosynthesis and significantly high yield especially among long-stemmed species (A. cruentus - $53.7 \mathrm{t} \mathrm{ha}^{-1}$ and $A$. caudatus - $49.0 \mathrm{tha}^{-1}$ ). Analysis of seed productivity showed that only one species of amaranth (A. cruentus - $1.32 \mathrm{t} \mathrm{ha}^{-1}$ ) had time to form seeds in full maturity in all years of the experiment. In other species, seed maturation in climatic conditions of the experiment was not observed due to higher temperature requirements. Experiments with heat-loving amaranth in other climatic conditions prove the possibility of seed maturation of

Table 6: Dynamics of increase of fresh and dry mass of amaranth species (Amaranthus spp.) during the growing season in the year $2016\left(\mathrm{tha}^{-1}\right)$

\begin{tabular}{|c|c|c|c|c|}
\hline Growth stages & A. cruentus & A. caudatus & A. hybridus & A. spinosus \\
\hline \multicolumn{5}{|l|}{ Fresh mass $\left(\mathrm{t} \mathrm{ha}^{-1}\right)$} \\
\hline Vegetative state & $12.4 \mathrm{a}$ & $12.9 \mathrm{a}$ & $9.3 \mathrm{~b}$ & $6.3 c$ \\
\hline Inflorescence formation & $31.2 \mathrm{a}$ & $29.7 \mathrm{a}$ & $19.4 \mathrm{~b}$ & $15.0 \mathrm{c}$ \\
\hline Flowering & $57.2 \mathrm{a}$ & $53.8 \mathrm{a}$ & $39.5 \mathrm{~b}$ & $28.6 \mathrm{c}$ \\
\hline \multicolumn{5}{|l|}{ Dry mass $\left(\mathrm{t} \mathrm{ha}^{-1}\right)$} \\
\hline Vegetative state & $2.0 \mathrm{a}$ & $2.1 \mathrm{a}$ & $1.5 \mathrm{~b}$ & $1.0 \mathrm{c}$ \\
\hline Inflorescence formation & $5.5 \mathrm{a}$ & $5.2 \mathrm{a}$ & $3.4 \mathrm{~b}$ & $2.8 \mathrm{c}$ \\
\hline Flowering & $10.6 \mathrm{a}$ & $10.0 \mathrm{a}$ & $6.3 \mathrm{~b}$ & $4.6 \mathrm{c}$ \\
\hline \multicolumn{5}{|l|}{ Dry matter content (\%) } \\
\hline Vegetative state & $16.1 \mathrm{a}$ & $16.2 \mathrm{a}$ & $16.0 \mathrm{a}$ & $16.2 \mathrm{a}$ \\
\hline Inflorescence formation & $17.6 \mathrm{a}$ & $17.5 \mathrm{a}$ & $17.5 \mathrm{a}$ & $17.6 \mathrm{a}$ \\
\hline Flowering & $18.5 \mathrm{a}$ & $18.2 \mathrm{a}$ & $18.2 \mathrm{a}$ & $18.3 \mathrm{a}$ \\
\hline
\end{tabular}

Values within a lines marked with different letter are significantly different at $p<0.05$.. 
Table 7: Yield of amaranth species $\left(\mathrm{t} \mathrm{ha}^{-1}\right)$

\begin{tabular}{lllll}
\hline Years & A. cruentus & A. caudatus & A. hybridus & A. spinosus \\
\hline Green fresh mass (biomass) & & & \\
\hline 2015 & $48.0 \mathrm{a}$ & $42.6 \mathrm{a}$ & $37.2 \mathrm{~b}$ & $25.4 \mathrm{c}$ \\
2016 & $57.2 \mathrm{a}$ & $53.8 \mathrm{a}$ & $39.5 \mathrm{~b}$ & $28.6 \mathrm{c}$ \\
2017 & $55.9 \mathrm{a}$ & $50.6 \mathrm{a}$ & $40.2 \mathrm{~b}$ & $28.0 \mathrm{c}$ \\
Average & $53.7 \mathrm{a}$ & $49.0 \mathrm{a}$ & $39.0 \mathrm{~b}$ & $27.3 \mathrm{c}$ \\
\hline Grain (seeds) & & & - & - \\
2015 & 1.11 & - & - & - \\
2016 & 1.46 & - & - & - \\
2017 & 1.40 & - & - & - \\
Average & 1.32 & - & & \\
\hline
\end{tabular}

Values within a lines marked with different letter are significantly different at $p<0.05$..

Table 8: Chemical composition and nutritional value of biomass (Amaranthus spp.)

\begin{tabular}{|c|c|c|c|c|}
\hline Indicators & A. cruentus & A. caudatus & A. hybridus & A. spinosus \\
\hline \multicolumn{5}{|c|}{ Chemical composition (\% in dry mass) } \\
\hline Protein & 20.87 & 21.56 & 20.75 & 21.12 \\
\hline Lipids & 1.38 & 1.50 & 1.33 & 1.28 \\
\hline Cellulose & 17.54 & 16.12 & 18.06 & 15.90 \\
\hline Ash elements & 18.73 & 18.35 & 17.98 & 18.07 \\
\hline Sugar & 2.65 & 2.54 & 2.76 & 3.05 \\
\hline \multicolumn{5}{|c|}{ Nutritional value ( $\mathrm{g} \mathrm{kg}^{-1}$ dry mass) } \\
\hline Protein & 161.70 & 162.43 & 160.74 & 162.78 \\
\hline Calcium & 26.39 & 26.14 & 25.98 & 27.09 \\
\hline Phosphorus & 4.19 & 4.49 & 3.57 & 4.54 \\
\hline Carotene (mg) & 99 & 93 & 79 & 88 \\
\hline Vitamin C (mg) & 23 & 24 & 31 & 36 \\
\hline
\end{tabular}

all amaranth species (Caselato-Sousa \& Amaya-Farfan, 2012).

\subsection{CHEMICAL COMPOSITION AND NUTRI- TIONAL VALUE OF AMARANTH SPECIES (Amaranthus spp.)}

The value of forage crops in agriculture is determined by the nutrient content of green biomass for silage and seeds. Main nutritional information of amaranth species is presented in Table 8.

The chemical composition of biomass indicates a quite good feed value of amaranth species (Amaranthus spp.). Protein content did not differ significantly among amaranth species and ranged from $20.75 \%$ to $21.56 \%$ in dry mass. The same pattern is established with other indicators of nutritional value comparing species of amaranth (Andini et al., 2013)It can be stated that the soil and climatic conditions of the experiment were quite favorable for the accumulation of nutrients in the fresh green biomass of all amaranth species (Amaranthus spp.).

\section{CONCLUSIONS}

The results of comparative study of amaranth species (Amaranthus spp.) indicated that soil and climatic conditions of the Chuvash Republic were quite favorable for growing all species to produce green biomass for silage. But given that amaranth is more demanding to heat than to moisture it is preferable to grow more rapidly developing species with a growing season of not more than 100 days (A. cruentus, A. caudatus) in order 
to avoid being damaged by early frosts. Comparing the dynamics of changes in growth parameters in 2016 year (height and diameter of stem, number and area of leaves, mass of plants), it was found that long-stemmed species of amaranth (A. cruentus, A. caudatus) are more suitable for growing under experimental conditions. Analysis of nutritional value of green biomass did not reveal significant differences among the studied species, but taking into account the higher yield of long-stemmed species (A. cruentus, A. caudatus) their advantage over medium(A. hybridus) and short-stemmed species (A. spinosus) became evident. As a result it can be concluded that the most adapted amaranth species (Amaranthus spp.) for soil and climatic conditions of the Chuvash Republic are A. cruentus and A. caudatus for fodder purposes and $A$. cruentus for grain purposes.

\section{REFERENCES}

Abbas, A. El-Ghamery, Ahmed, M. Sadek, Ola, H. Abd El Bar. (2017). Comparative anatomical studies on some species of the genus Amaranthus (Family: Amaranthaceae) for the development of an identification guide. Annals of agricultural sciences 62(1), 1-9. https://doi.org/10.1016/j. aoas.2016.11.001

Amicarelli, V. \& Camaggio, G. (2012). Amaranthus: a crop to rediscover. Ware international 2, 4-11.

Andini, R., Yoshida, S., Ohsawa, R. (2013). Variation in protein content and amino acids in the leaves of grain, vegetable and weedy types of amaranths. Agronomy, 3, 391-403. https://doi.org/10.3390/agronomy3020391

Archipova, N. S., Breus, I. P. (2004). Productivity and nutritional value of amaranth under the influence of chloride and sulfate soil salinization. Agricultural biology, 39, 92-100. [in Russian].

Betschart, A. A., Irving, V., Shepherd A. D., Saunders, R. M. (2001). Amaranthus cruentus: milling characteristics, distribution of nutrients within seed components, and the effects of temperature on nutritional quality. Journal of Food Society 46, 1181-1187. https://doi. org/10.1111/j.1365-2621.1981.tb03019.x

Bruinsma, J. (2009). The resource outlook to 2050: By how much do land, water and crop yields need to increase by 2050 ? In proceedings of the technical meeting of experts on how to feed the world in 2050, in 24-26 June in Rome (133). Italy: Food and Agriculture Organization (FAO).

Carlquist, S. (2003). Wood and stem anatomy of woody Amarantaceae: ecology, systematic and problems of defining rays in dicotyledous. Botanical journal of the Linnean society, 143, 1-9. https://doi.org/10.1046/j.1095-8339.2003.00197.x

Caselato-Sousa, V. M. \& Amaya-Farfán, J. (2102). State of knowledge on amaranth grain: a comprehensive review. Journal of Food Science, 4, 93-104. https://doi.org/10.1111/ j.1750-3841.2012.02645.x

Godfray, H., Crute, I., Haddad, L., Lawrence, D., Muir, J., Pretty, J., Robinson, S., Thomas, S., Toulmin, C. (2010). Food secu- rity: The challenge of feeding 9 billion people. Science, 327 , 812-818. https://doi.org/10.1126/science.1185383

Costea, M. Sanders, A., Waines, G. (2001). Preliminary results towards a revision of the Amaranthus hybridus complex (Amarantaceae). Sida, 19, 931-974.

Dmitrieva O. F. (1993). Agrotechnics of cultivation of the purple amaranth in the conditions of the Chuvashia: The dissertation on competition of the degree of the candidate of agricultural Sciences. - Moscow: Agrarian University [in Russian].

Dmitrieva O. F. (2018a). Features of growth and development of amaranth in soil-climatic conditions of the Chuvash republic. In P. Results of the international scientific-practical conference, in Tumen (pp. 4-6). Ufa: Agency for International Studies [in Russian].

Dmitrieva O. F. (2014). Features of growth and development of Amaranthus cruentus L. at various times and methods of sowing in soil and climatic conditions of the Chuvash Republic. Bulletin of I. Yakovlev Chuvash State Pedagogical University, 84, 63-67. [in Russian].

Dmitrieva O. F. (2018c). Growth and development of Amaranthus cruentus L. in soil and climatic conditions of the Chuvash Republic. Successes of modern natural science, 11, 30-36, [in Russian].

Dmitrieva O. F. (2018b). Study of water consumption of Amaranthus cruentus L. in the conditions of the Chuvash Republic. International scientific Research Journal 76, 17-20 [in Russian].

Ebert, A. W. (2010). Potential of underutilized traditional vegetables and legume crops to contribute to food and nutritional security, income and more sustainable production systems. Sustainability, 6, 319-335. https://doi.org/10.3390/ su6010319

Fadeeva N. A. \& Dmitrieva O. F. (2017). Influence of the sowing time on the development of seedlings of small-seeded flower crops. In P.: Rational nature management and socioeconomic development of rural areas as the basis for the effective functioning of the agro-industrial complex of the region. (pp. 45-48). Cheboksary: CHSAA [in Russian].

Juan, C. K. (2007). Electrophoretic characteristics of Amaranthus L, seed proteins and its systematic implication. Botanical journal of the Linnean society, 2, 57-63. https://doi. org/10.1111/j.1095-8339.2007.00665.x

Kaufman C. S. (1992). Realizing the potential of grain Amaranth. Food Reviews International, 8, 5-21. https://doi. org/10.1080/87559129209540927

Magomedov, I. M. (2008). Physiological bases of amaranth competitiveness. Successes of modern natural science, 5, 57-59 [in Russian].

Mlakar, S. G., Turinek, M., Jakop, M., Bavec, M. Bavec, F. (2010). Grain Amaranth as an alternative and perspective crop in temperate climate. Journal for Geography, 5(1), 135-145.

Mlakar, S. G, Turine, M., Jakop, M., Bavec, M. Bavec, F. (2009). Nutrition value and use of grain amaranth: potential future application in bread making. Agricultura, 6, 43-53.

Norman, J. C. \& Shongwe, V. D. (1993). Influence of some cultural practices on the yield and quality of amaranth (Amaranthus hybridus L.). Advances in horticultural science, 7 , 169-172. 
Ozsoy, N., Yilmaz, T., Kurt. O., Can, A., Yanardag, R. (2009). In vitro antioxidant activity of Amaranthus lividus L. Food Chemistry, 116(4), 867-872. https://doi.org/10.1016/j.foodchem.2009.03.036

Pospisil, A., Pospisil, M., Macesic, D., Svecnjak, Z. (2009). Yield and quality of forage sorghum and different amaranth species (Amaranthus spp.) biomass. Agriculture conspectus scientific, 74(2), 85-89.

Putnam, D. H. (2007). Center for alternative plant and animal products Minnesota extension services. University of Minnesota. St Paul Mn. 1-5.

Rastogi, A. \& Shukla, S. (2013). Amaranth: a new millennium crop of nutraceutical values. Food science and nutrition 53, 109-125. https://doi.org/10.1080/10408398.2010.517876

Russian Organization for Standardization (2012). Near infrared spectroscopy (State standard No. 32041-2012. Retrieved from https://www.shimadzu.ru/.

Saratovsky, L. I., Vashchenko, E. G, Fedotov, V. A., Kazazyan, V. V. (2018). Elements of varietal technology of amaranth cultivation in the steppe zone of the Central black earth region. Bulletin of the Voronezh state agrarian University, 1(56), 22-31. [in Russian]. https://doi.org/10.17238/ issn2071-2243.2018.1.22
Shishova, L. L., Tonkonogov, V. D., Lebedeva, I. I., Gerasimova, M. I. (2004). Classification and diagnostics of soils in Russia. Smolensk: Oikumen [in Russian].

Taipova, R. M. \& Kuluev, B. R. (2015). Amaranth: features of culture, application, and prospects of cultivation in Russia. Biomics, 4(2), 84-90. [in Russian].

Thapa, R. \& Blair, M. (2018). Morphological assessment of cultivated and wild amaranth species diversity. Agronomy, 8, 272-280. https://doi.org/10.3390/agronomy8110272

Topwal M. (2019). A review on Amaranth: nutraceutical and virtual plant for providing food security and nutrients. Acta Scientific Agriculture, 3(1), 9-15.

Ulbricht, C., Abrams, T., Conquer, J., Costa, D., Serrano, J. M. G., Taylor, S., Varghese, M. (2009). An evidencebased systematic review of amaranth (Amaranthus spp.) by the natural standard research collaboration. Journal of dietary supplements, 6(4), 390-417. https://doi. org/10.3109/19390210903280348

Uusikua, N. P., Oelofsea, K. G., Duodub, M. J., Besterc, M. Megan, J. (2010). Nutritional value of leafy vegetables of sub-Saharan Africa and their potential contribution to human health. Food composition and analysis, 23, 499-509. https://doi.org/10.1016/j.jfca.2010.05.002 